\title{
THE INFLUENCE OF ANTIPSYCHOTICS ON THE QUALITY OF LIFE OF PATIENTS WITH SCHIZOPHRENIA IN A LONG-STAY PSYCHIATRIC FACILITY
}

\author{
Aleksandra Petrovic Kitic ${ }^{1}$, Slobodan Jankovic ${ }^{2}$ \\ ${ }^{1}$ Student of doctoral academic studies, Faculty of Medical Sciences, University of Kragujevac \\ ${ }^{2}$ Department of Pharmacology, Faculty of Medical Sciences, University of Kragujevac

\begin{abstract}
UTICAJ ANTIPSIHOTIKA NA IKVALITET ŽIVOTA PACIJENATA SA SHIZOFRENIJOM KOJU SU TRAJNO SMEŠTENI U ZAVODU ZA SMEŠTAJ ODRASLIH LICA „MALE PČELICE” KRAGUJEVAC
\end{abstract}

\author{
Aleksandra Petrović Kitić1 ${ }^{1}$, Slobodan Janković ${ }^{2}$ \\ ${ }^{1}$ Student akademskih doktorskih studija, Fakultet medicinskih nauka, Univerzitet u Kragujevcu \\ ${ }^{2}$ Katedra za farmakologiju, Fakultet medicinskih nauka, Univerzitet u Kragujevcu
}

Received / Primljen: 02.01.2014.

Accepted / Prihvaćen: 15.04.2014.

\section{ABSTRACT}

Introduction: Many factors concomitantly influence the quality of life of patients with schizophrenia in a long-stay psychiatric facility. The appropriate selection of antipsychotics and the intensity of their adverse effects exert a significant influence on the quality of life of these patients. The aim of this study was to identify the influence of antipsychotic-related factors on the quality of life of patients with schizophrenia.

Methods: The study included 102 beneficiaries at the Institute for Accommodation of Adults "Male Pčelice" in Kragujevac. The patients were interviewed on in one day using the questionnaire issued by the World Health Organization. The specified data were obtained from the health files of the beneficiaries. We performed a comparison between patients receiving only atypical antipsychotics, typical antipsychotics or a combination thereof.

Results: The patients who were receiving only atypical antipsychotics demonstrated better physical health quality of life scores in comparison to those who received combined antipsychotics (77.14 vs. 68.57; $U=332.0 ; p=0.02$ ). A statistically significant difference in the mental health quality of life domain was observed between groups of patients receiving various antipsychotic treatments (31.96 vs. 55.27 vs. 49.46; $c 2=7.02 ; p=0.03$ ).

Conclusion: Patients in a long-stay psychiatric facility who received atypical antipsychotics demonstrated a better quality of life in comparison to those who received typical antipsychotics, possibly due to the superior safety profile of atypical antipsychotics and a greater feeling of individual contentment.

Key words: Quality of life, chronic schizophrenia, quality of life domains, questionnaires

\section{SAŽETAK}

Uvod: Na kvalitet života osoba koje boluju od shizofrenije utiče mnogo faktora istovremeno. Kod pacijenata u institucionalnom smeštaju adekvatan izbor antipsihotika i intezitet neželjenih dejstva lekova ima veliki uticaj na kvalitet života ovih pacijenata. Cilj ove studije je bio da se utvrdi uticaj faktora vezanih za antipsihotike na kvalitet života pacijenata koji boluju od shizofrenije.

Metode: Istraživanjem je obuhvaćeno ukupno 102 korisnika Zavoda za smeštaj odraslih lica „Male Pčelice” Kragujevac. Korisnici su ispitani u samo jednom izabranom danu korišćenjem upitnika Svetske zdravstvene organizacije. Odredeni podaci su prikupljeni iz zdravstvenih kartona korisnika. Poređene su grupe korisnika koji koriste samo apitičan ili tipičan antipsihotik ili kombinaciju ove dve grupe antipsihotika.

Rezultati: Korisnici koji koriste samo atipičan antipsihotik imaju bolji skor fizičkog zdravlja od korisnika koji koriste kombinaciju antipsihotika $(77,14$ vs. 68,57; $U=$ 332,0; $p=0,02)$. Postoji statistički značajna razlika u skoru domena psihičkog zdravlja u zavisnosti od grupe antipsihotika koji je korisniku propisan (31,96 vs. 55,27 vs. 49,46; c2 = 7,02; $p=0,03$ ).

Zaključak: Korisnici ustanove za dugotrajan smeštaj psihijatrijskih bolesnika koji primaju apitične antipsihotike imaju bolji kvalitet života u odnosu na pacijente koji primaju tipične antipsihotike, verovatno zbog manje izraženih neželjenih dejstava atipičnih antipsihotika $i$ boljeg osećaja subjektivnog zadovoljstva.

Ključne reči: kvalitet života, hronična shizofrenija, domeni kvaliteta života, upitnici 


\section{INTRODUCTION}

The quality of life (QoL) of patients with schizophrenia depends on their social environment to a great extent. Patients residing in their own homes, outside of hospitals, exhibit improved QoL, which can be measured impartially using scales; however, a personal feeling of improvement is stronger in institutionalised patients, primarily due to the feeling of safety (1). In institutionalised patients, individual elements of QoL depend strongly on the intensity of negative symptoms, anxiety and depression (2).

Institutional accommodation of patients with schizophrenia is not a decisive driver of lower QoL per se; its effects are combined with the severity of patient symptoms, environmental support, educational level and concept of the illness (3). Proper selection of antipsychotics also exhibits a strong, positive influence on the QoL of these patients (4); however, the positive effects of medication are often absent or are not observed in the early stages of schizophrenia (5). In addition, the adverse effects of antipsychotics can considerably reduce patient QoL (6).

Because many factors concomitantly influence institutionalised patients with schizophrenia, the identification of interactions between these factors is crucial. The aim of this study was to identify the influence of antipsychoticsrelated factors on the quality of life of patients with schizophrenia.

\section{MATERIALS AND METHODS}

The study was conducted at the Institute for Accommodation of Adults "Male Pčelice" in Kragujevac. The Institute for Accommodation of Adults in Male Pčelice is a stationary institution for patients with chronic psychiatric disorders, who are cared for by a multi-disciplinary team, including psychiatrists, psychologists, general physicians and other medical staff. This institution accommodates patients, whose families cannot provide adequate care and who originate, from all of the regions in Serbia. The total capacity of the institution is 890 beds.

This study was designed as a cross-sectional study, and the patients were interviewed in a single day. The factors that influenced the QoL of the patients with schizophrenia were analysed. The patients' quality of life was evaluated using a special questionnaire designed by the World Health Organization, for which approval was obtained (7). The World Health Organization Quality of Life Scale Brief Version (WHOQOL-BREF) is used for patients with schizophrenia, and this scale has been validated (8). The WHOQOL-BREF is based on four domain structures: physical health, psychologicapsychological healthl, social relationships and environment. This scale contains a total of 26 questions. The domain scores are scaled in the positive direction (i.e., higher scores denote higher quality of life). The mean score of items within each domain is used to calculate the domain score. The transformation method converts the domain scores to a 0-100 scale. The study population was comprised entirely of patients who were diagnosed as suffering from schizophrenia according to the tenth International Classification of Diseases (ICD - 10) (9).

The research study enrolled 102 beneficiaries of this institution. The exclusion criteria were a patient's inability to participate in the study and adequately answer all of the questions, illiteracy and visual disorders that rendered reading the questionnaire impossible. Each patient received information about study participation in both written and oral forms. Study participation was voluntary, and the patients were included in the study after their approval.

Next, the patients were given the questionnaire to fill out; the obtained data remained protected. A portion of the study data, such as sex, age, marital status, education, diagnosis, length of stay at the institution, type of antipsychotic medication, administered antipsychotic and antipsychotic dosage, was obtained from the patients' health files.

The study was approved by the Ethical Committee of the Institute for Accommodation of Adults "Male Pčelice" in Kragujevac.

\section{Statistical data processing}

The obtained data were first processed using methods for descriptive statistics. Continuous data are presented as measures of central tendency (mean value) and distribution (standard deviation), and the categorical variables are shown in percentages and absolute numbers. Differences in the continuous variable values between groups were evaluated using non-parametric tests (Mann-Whitney and Kruskal-Wallis), and differences in the distribution of the categorical variable values were tested by using the Chisquare method. The maximum acceptable probability for the null hypotheses was 0.05 . The commercial program SPSS for Windows 19 was used for data analysis.

\section{RESULTS}

One hundred and two patients (63 males and 39 females) were interviewed in a single day. Their baseline characteristics (psychiatric diagnoses and prescribed antipsychotic therapy with dose regimens and defined daily doses) are shown in detail in Table 1 . The quality of life scores observed among the various patient subgroups and differences among the groups are shown in Table 2 if they achieved significance; the remaining comparisons are described in the following text.

No statistically significant differences were found for the physical health domain scores based on sex (74.29 vs. 71.43; $\mathrm{U}=1217.5 ; \mathrm{p}=0.939)$, educational level (57.42 vs. 48.82 vs. $49.63 ; \mathrm{c} 2=1.72 ; \mathrm{p}=0.423)$, marital status $(74.29$ vs. $74.29, \mathrm{U}=1168.5 ; \mathrm{p}=0.497)$, age (52.27 vs. 51.45 vs. $50.70 ; \mathrm{c} 2=0.018 ; \mathrm{p}=0.991)$, diagnosis ( 48.35 vs. 54.27 vs. 


\begin{tabular}{|c|c|c|}
\hline \multicolumn{2}{|c|}{ Observed parameters } & Obtained values \\
\hline \multirow{2}{*}{$\operatorname{Sex~n~}(\%)$} & Males & $63(61.8 \%)$ \\
\hline & Females & $39(38 . \%)$ \\
\hline \multirow{3}{*}{ Highest degree of education n (\%) } & Primary school & $30(29.4 \%)$ \\
\hline & Secondary school & $53(52.0 \%)$ \\
\hline & University & $19(18.6 \%)$ \\
\hline \multirow{2}{*}{ Marital status n (\%) } & Lives alone & $59(57.8 \%)$ \\
\hline & Separated & $43(42.2 \%)$ \\
\hline \multirow{3}{*}{ Age n (\%) } & $18-40$ years & $15(14.7 \%)$ \\
\hline & $40-60$ years & $77(75.5 \%)$ \\
\hline & $>60$ years & $10(9.8 \%)$ \\
\hline \multirow{5}{*}{ Diagnosis n (\%) } & Paranoid schizophrenia & $36(35.3 \%)$ \\
\hline & Hebephrenic schizophrenia & $31(30.4 \%)$ \\
\hline & Residual schizophrenia & $20(19.6 \%)$ \\
\hline & Permanent possessive mental illness & $9(8.8 \%)$ \\
\hline & Schizoaffective mental disorder & $6(5.9 \%)$ \\
\hline \multirow{2}{*}{ Length of stay at institution $\mathrm{n}(\%)$} & $<15$ years & $69(67.6 \%)$ \\
\hline & $>15$ years & $33(32.4 \%)$ \\
\hline \multirow{3}{*}{ Type of antipsychotic n (\%) } & Typical & $13(12.7 \%)$ \\
\hline & Atypical & $75(73.5 \%)$ \\
\hline & Combined & $14(13.7 \%)$ \\
\hline \multirow{4}{*}{ Prescribed antipsychotic n (\%) } & Haloperidol & $13(12.7 \%)$ \\
\hline & Risperidone & $53(52.0 \%)$ \\
\hline & Risperidone and haloperidol & $14(13.7 \%)$ \\
\hline & Clozapine & $22(21.6 \%)$ \\
\hline \multirow{2}{*}{ Number of antipsychotics per patient $n(\%)$} & One antipsychotic & $88(86.3 \%)$ \\
\hline & Two antipsychotics & $14(13.7 \%)$ \\
\hline \multirow{3}{*}{ Daily dosage n (\%) } & Once per day & $16(15.7 \%)$ \\
\hline & Twice per day & $64(62.7 \%)$ \\
\hline & Three times per day & $22(21.6 \%)$ \\
\hline \multirow{2}{*}{ Defined daily dose n (\%) } & $<\mathrm{DDD}$ & $62(60.8 \%)$ \\
\hline & $>\mathrm{DDD}$ & $40(39.2 \%)$ \\
\hline
\end{tabular}

Table 1. General characteristics of patients.

44.55 vs. 55.89 vs. $72.67 ; \mathrm{c} 2=5.08 ; \mathrm{p}=0.279)$, length of stay at the institution (65.71 vs. $74.29 ; \mathrm{U}=154.5 ; \mathrm{p}=0.067$ ), daily antipsychotics dosage ( 42.59 vs. 54.46 vs. 49.36 ; c $2=$ 2.217; $\mathrm{p}=0.330$ ) or defined daily dose (52.27 vs. 50.31 ; U $=1192.5 ; \mathrm{p}=0.744)$.

No statistically significant differences were forin the mental health domain scores were obtained based on sex (70.00 vs. $73.33 ; \mathrm{U}=1110.5 ; \mathrm{p}=0.414$ ), educational level
( 56.78 vs. 46.84 vs. $56.16 ; \mathrm{c} 2=2.770 ; \mathrm{p}=0.250)$, age $(55.53$ vs. 50.87 vs. $50.30 ; \mathrm{c} 2=0.333 ; \mathrm{p}=0.846)$, marital status (70.00 vs. $70.00 ; \mathrm{U}=1253.5 ; \mathrm{p}=0.919$ ), diagnosis ( 49.57 vs. 51.11 vs. 54.08 vs. 48.89 vs. $60.42 ; \mathrm{c} 2=0.934 ; \mathrm{p}=0.920)$, length of stay at the institution (20.53 vs. 24.94; $U=188.0$; $\mathrm{p}=0.293$ ), number of prescribed antipsychotics (51.82 vs. $49.46 ; \mathrm{U}=587.5 ; \mathrm{p}=0.781$ ) or defined daily dose (49.83 vs. 54.09; $\mathrm{U}=1136.5 ; \mathrm{p}=0.476)$. 


\begin{tabular}{|l|l|l|l|l|}
\hline Parameter & Value & $\begin{array}{l}\text { Physical } \\
\text { health } \\
\text { domain score }\end{array}$ & $\begin{array}{l}\text { Mental } \\
\text { health } \\
\text { domain } \\
\text { score }\end{array}$ & $\begin{array}{l}\text { Statistical test and } \\
\text { significance }\end{array}$ \\
\hline Antipsychotics group & $\begin{array}{l}\text { Atypical } \\
\text { Typical/atypical combination }\end{array}$ & $\begin{array}{l}77.14 \\
68.57\end{array}$ & & $\begin{array}{l}\mathrm{U}=332.0 ; \quad \mathrm{p}= \\
0.02\end{array}$ \\
\hline $\begin{array}{l}\text { Risperidone vs. } \\
\text { risperidone+haloperidol }\end{array}$ & $\begin{array}{l}\text { Risperidone } \\
\text { Risperidone +haloperidol }\end{array}$ & 74.2968 .57 & & $\mathrm{U}=230.5 ;$ \\
$\mathrm{p}=0.03$
\end{tabular}

Table 2. Significant differences in the quality of life scores observed in the study.

No statistically significant differences were observed for the social health domain scores based on sex (66.67 vs. 73.33; $\mathrm{U}=1166.5 ; \mathrm{p}=0.666)$, educational level (55.77 vs. 48.39 vs. $53.45 ; \mathrm{c} 2=1.32 ; \mathrm{p}=0.516)$, marital status $(66.67$ vs. $73.33 ; \mathrm{U}=1031.0 ; \mathrm{p}=0.103)$, age (50.70 vs. 52.05 vs. $48.50 ; \mathrm{c} 2=0,143 ; \mathrm{p}=0,931)$, diagnosis (46.89 vs. 59.56 vs. 47.28 vs. 46.33 vs. $59.33 ; \mathrm{c} 2=4.38 ; \mathrm{p}=0.357)$, length of stay at the institution (19.83 vs. $25.27 ; \mathrm{U}=177.5 ; \mathrm{p}=$ 0.191 ), antipsychotics group (39.27 vs. 53.67 vs. 51.21 ; c2 $=2.69 ; \mathrm{p}=0.260)$, type of prescribed antipsychotics $(39.27$ vs. 52.47 vs. 51.21 vs. $56.57 ; \mathrm{c} 2=2.99 ; \mathrm{p}=0.392)$, number of prescribed antipsychotics per patient (73.33 vs. 70.00; $\mathrm{U}$ $=612.0 ; \mathrm{p}=0.969)$, daily antipsychotics dosage (39.59 vs. 55.30 vs. $49.11 ; \mathrm{c} 2=3.88 ; \mathrm{p}=0.144)$ or defined daily dose ( 50.64 vs. $52.84 ; \mathrm{U}=1186.5 ; \mathrm{p}=0.711$ ).

No statistically significant differences were in the environmental domain scores were found based on sex (62.50 vs. $67.05 ; \mathrm{U}=1058.0 ; \mathrm{p}=0.239$ ), marital status (50.52 vs. $52.85 ; \mathrm{U}=1210.50 ; \mathrm{p}=0.693$ ), age (55.27 vs. 51.47 vs. 46.10 ; $\mathrm{c} 2=0.58 ; \mathrm{p}=0.748$ ), diagnosis (50.26 vs. 46.24 vs. 53.83 vs. 60.50 vs. $64.83 ; \mathrm{c} 2=3.24 ; \mathrm{p}=0.518$ ), type of antipsychotics ( 46.23 vs. 52.86 vs. $49.11 ; \mathrm{c} 2=0.67 ; \mathrm{p}=0.716$ ), length of stay at the institution (21.27 vs. $24.58 ; \mathrm{U}=199.0 ; \mathrm{p}=0.431$ ), type of prescribed antipsychotics (46.23 vs. 52.86 vs. 49.11 ; $\mathrm{c} 2=1.39 ; \mathrm{p}=0.709)$, number of prescribed antipsychotics per patient (51.88 vs. $49.11 ; \mathrm{U}=582.5 ; \mathrm{p}=0.744$ ), daily antipsychotics dosage ( 42.16 vs. 54.78 vs. $48.75 ; \mathrm{c} 2=2.59$; p $=0.274$ ) or defined daily dose (52.33 vs. $50.21 ; \mathrm{U}=1188.5$; $\mathrm{p}=0.723)$.

A statistically significant difference in the environmental domain scores was observed based on the beneficiaries' educational status (i.e., between those who completed primary school or acquired a university degree) (71.25 vs. 65.00; $\mathrm{U}=172.0 ; \mathrm{p}=0.02$ ).

\section{DISCUSSION}

Numerous studies of the benefits of atypical antipsychotics in the treatment of schizophrenia, including reduced side effects, cognitive improvement, less pronounced extrapyramidal syndrome and better medication tolerance, have led to the increased administration of these antipsychotics in comparison to typical antipsychotics. Various literature reports have discussed the quality of life of patients treated with typical and atypical antipsychotics.

In summary, the results of our study indicated that the physical and mental health domain scores were dependent on the prescribed antipsychotic. The patients who received atypical antipsychotics alone demonstrated better scores for physical and mental health than those who were administered combined antipsychotics or only typical antipsychotics. Zaghdoudi et al presented similar results. The authors reported that the QoL of patients who were prescribed atypical antipsychotics was better than that of patients who received typical antipsychotics due to less frequent side effects from the atypical antipsychotics, especially extrapyramidal syndrome (10). Zhang et al also observed that the introduction of atypical antipsychotics into the therapy of patients with chronic psychiatric disorders resulted in positive effects on patient quality of life, due to their superior safety profile (11). This statement was also confirmed by the fact that, in our study, the patients who were administered risperidone alone exhibited better physical health scores than those who were prescribed both risperidone and haloperidol. A study conducted by Midori et al found that patients who received atypical antipsychotics reported improved feelings of individual satisfaction, due to a reduction in side effects, and general 
contentment, in comparison to the patients who received typical antipsychotics (12).

The patients who were administered risperidone or clozapine alone exhibited better mental health scores than those who were prescribed haloperidol. Additionally, patients who received only one antipsychotic medication demonstrated better physical health scores than those who received two antipsychotics. When compared to patients who were administered typical antipsychotics, those who received atypical antipsychotics required noticeably fewer interventions with anticholinergic and anxiolytic medications to treat side effects (13). The treatment of patients who had suffered from psychiatric diseases for a long time revealed that the administration of atypical antipsychotics, in comparison to typical antipsychotics, increased the probability of complete remission (14).

The results of our study indicated that the mental health scores of patients who were administered antipsychotics once per day were higher than those of patients who received antipsychotics three times per day. Regarding compliance, another study demonstrated that the patients who were administered atypical antipsychotics exhibited better tolerance of their side effects and were therefore more accepting of their medication (15). The patients who were excluded from therapy with typical antipsychotics and were administered atypical antipsychotics such as risperidone and olanzapine demonstrated improvement in their general symptoms of schizophrenia and amelioration of undesirable motoric effects (16). A statistically significant difference in the environmental domain score was observed based on the patients' educational level, between patients who had only completed primary school and those who had obtained an academic education.

In contrast to these findings, other papers deny the benefits of atypical antipsychotics. In their study, Jones et al did not observe any superiority of atypical antipsychotics in regards the reduction of treatment costs, improvement of QoL and alleviation of symptoms in comparison to typical antipsychotics (17). Loffler et al reported that no significant differences in the individual improvement of the patients were found between typical and atypical antipsychotics treatments (18). Diaz et al suggested that there are no differences in the response to therapy between patients who were administered typical or atypical antipsychotics (19).

The limitations of our study include the relatively small number of patients and single centre analysis. Because the study was cross-sectional, we were unable to observe the influence of previous therapeutic protocols and metabolic changes associated with the use of atypical antipsychotics.

The results of this study indicate that patients in a long-stay psychiatric facility who are administered atypical antipsychotics exhibit better QoL in comparison to those who receive typical antipsychotics, possibly due to the improved safety profile of atypical antipsychotics and greater feelings of individual contentment. To more successfully monitor the effect of antipsychotics in cases of schizophrenia, doctors and other medical staff should pay attention to individual feelings of contentment among their patients in addition to performing an impartial evaluation. An improved understanding of antipsychotic medications is necessary to improve therapeutic strategies in the treatment of schizophrenia.

\section{ACKNOWLEDGEMENTS}

This study was partially supported by Grant No. JP-1311 from the Faculty of Medical Sciences, Kragujevac.

\section{REFERENCES}

1. Chan GW, Ungvari GS, Shek DT, Leung Dagger JJ. Hospital and community-based care for patients with chronic schizophrenia in Hong Kong- quality of life and its correlates. Soc Psychiatry Psychiatr Epidemiol 2003; 38(4): 196-203.

2. Salomé F, Petitjean F, Germain C, Demant JC. The subjective quality of life of patients with schizophrenia: influence of psychopathology and patients' expectations. A comparative study. Encephale 2004; 30(1): 60-8.

3. Rössler W, Salize HI, Cucchiaro G, Reinhard I, Kernig C. Does the place of treatment influence the quality of life of schizophrenics? Acta Psychiatr Scand. 1999; 100(2): 142-8.

4. Nuss P, Tessier C. Antipsychotic medication, functional outcome and quality of life in schizophrenia: focus on amisulpride. Curr Med Res Opin. 2010; 26(4): 787-801.

5. Kane JM, Kim E, Kan HJ, Guo Z, Bates JA, Whitehead R, Pikalov A. Comparative utility of aripiprazole and haloperidol in schizophrenia: post hoc analysis of two 52-week, randomized, controlled trials. Appl Health Econ Health Policy. 2009; 7(2): 109-19.

6. Bebbington PE, Angermeyer M, Azorin JM, Marwaha S, Marteau F, Toumi M. Side-effects of antipsychotic medication and health-related quality of life in schizophrenia. Acta Psychiatr Scand Suppl. 2009; 438: 22-8.

7. www.who.int

8. Mas-Expósito L, Amador-Campos JA, Gómez-Benito J, Lalucat-Jo L. The World Health Organization Quality of Life Scale Brief Version: a validation study in patients with schizophrenia. Qual Life Res. 2011; 20(7): 1079-89.

9. World Health Organization. ICD-10 Chapter V. Diagnostic Criteria for Research. Genova: WHO, 1993.

10. Zaghdoudi L, Homri W, Belaid S, Ben Bechir M, Labbane R. Quality of life of patient with schizophrenia treated by conventional and atypical neuroleptics. Tunis Med. 2009; 87(9): 593-8.

11. Zhang PL, Santos JM, Newcomer J, Pelfrey BA, Johnson MC. Impact of atypical antipsychotics on quality of life, self-report of symptom severity, and demand of services in chronically psychotic patients. Schizophr Res. 2004; 71(1): 137-44. 
12. Midori Fujikawa, Takashi Togo, Asuka Yoshimi et al Evaluation of subjective treatment satisfaction with antipsychotics in schizophrenia patients. Progress in Neuro Psychopharmacology \& Biological Psychiatry 2008; 32: 755-760.

13. Menzin J, Boulanger L, Friedman M, Mackell J, Lloyd JR. Treatment adherence associated with conventional and atypical antipsychotics in a large state Medicaid program. Psychiatr Serv 2003; 54: 719-23.

14. Lambert M, Schimmelmann BG, Naber D, Schacht A, Karow A,Wagner T, et al Prediction of remission as a combination of symptomatic and functionalremission and adequate subjective well-being in 2960 patients with schizophrenia. J Clin Psychiatry 2006; 67: 1690-7.

15. Dolder CR, Lacro JP, Dunn LB, Jeste DV. Antipsychotic medication adherence: is there a difference between typical and atypical agents. Am J Psychiatry 2002; 159: 103-8.

16. Ritchie CW, Chiu E, Harrigan S, Hall K, Hassett A, Macfarlane $S$ et al The impact upon extra-pyramidal side effects, clinical symptoms and quality of life of a switch from conventional to atypical antipsychotics (risperidone or olanzapine) in elderly patients with schizophrenia. Int J Geriatr Psichiatry 2003; 18(5): 432-40.

17. Jones PB, Barnes TR, Davies L, Dunn G, Lloyd H, Hayhurst KP, et al Randomized controlled trial of the effect on quality of life of second- vs firstgeneration antipsychotic drugs in schizophrenia: Cost Utility of the Latest Antipsychotic Drugs in Schizophrenia Study (CUtLASS 1). Arch Gen Psychiatry 2006; 63: 1079-87.

18. Loffler W, Kilian R, Toumi M, Angermeyer MC. Schizophrenic patients' subjective reasons for compliance and noncompliance with neuroleptic treatment. Pharmacopsychiatry 2003; 36: 105-12.

19. Diaz E, Neuse E, Sullivan MC, Pearsall HR, Woods SW. Adherence to conventional and atypical antipsychotics after hospital discharge. J Clin Psychiatry 2004; 65: 354-60. 